\title{
PENGOBATAN TRADISIONAL PADA MASYARAKAT KOTA PRABUMULIH PROPINSI SUMATERA SELATAN
}

\section{TRADITONAL MEDICINE IN THE PEOPLE OF PRABUMULIH CITY SOUTH SUMATRA PROVINCE}

\author{
Rismadona \\ Balai Pelestarian Nilai dan Budaya Sumatera Barat \\ Jln. Raya Belimbing No. 16 A, Kuranji, Padang \\ E-mail: rismadona42@yahoo.com \\ Naskah diterima 8 Oktober 2018, diterima setelah perbaikan 23 Oktober 2018, \\ disetujui untuk dicetak 28 November 2018
}

\begin{abstract}
Abstrak
Tradisi pengobatan tradisional masyarakat Kota Prabumulih mempercayai pengobatan yang bersifat gaib. Penelitian ini menggunakan metode kualitatif yang berupaya menggali alasan masyarakat mempercayai pengobatan tradisional melalui wawancara mendalam. Pengalaman, sikap, dan tindakan yang dilakukan masyarakat terhadap pengobatan tradisional juga mengalami pergeseran tentang tradisi kepercayaan pengobatan tradisional yang bersifat hal gaib.
\end{abstract}

Kata kunci: Pengobatan Tradisional, Masyarakat, Kota Prabumulih

\begin{abstract}
The Tradition of Traditional Medicine of the Prabumulih City Community who believe in medicine that is supernatural. Current research uses qualitative methods that provide information that allows people to trust. Experience, attitudes, and movements carried out by the community towards traditional medicine also illustrate various traditional traditions that are supernatural.
\end{abstract}

Keywords: Traditional Medicine, Society, Prabumulih City

\section{PENDAHULUAN}

Pengobatan secara tradisional merupakan kebiasaan yang berlaku pada masyarakat yang dilakukan secara terus menerus dari nenek moyang hingga generasi berikutnya. Tradisi ini merupakan upaya masyarakat dalam melakukan pengobatan untuk melawan penyakit yang terjadi pada masyarakat itu sendiri. Sebelum masyarakat mengenal ilmu medis dan kedokteran pada tempo dulu, mereka cenderung melakukan pengobatan pada dukun yang dipercayai mampu mengobati penyakit baik secara jasmani maupun rohani melalui terawang bathin. 
Jenis pengobatan tradisional di Indonesia secara garis besar terdiri dari pengobatan tradisional dengan ramuan obat, pengobatan tradisional spritual/kebathinan, pengobatan tradisional dengan memakai peralatan/perangsang dan pengobatan tradisional yang telah mendapat pengarahan dan pengaturan pemerintah, sementara itu pengobatan tradisional spritual atau kebathinan terdiri dari pengobatan tradisional atas dasar kepercayaan, pengobatan tradisional atas dasar agama, pengobatan dengan dasar getar magnetis (Yacob,1996;61).

Pengobatan melalui dukun termasuk pada pengobatan tradisional atas dasar kepercayaan dalam upaya penyembuhan yang dilakukan untuk masyarakat itu sendiri. Pengobatan tersebut juga dilakukan pada masyarakat Prabumulih. Hal ini ditemui pada sebuah tradisi masyarakat Prabumulih Barat berkunjung ke Prabumulih Timur untuk melepaskan nazar ke Gunung Ibul karena dianggap sebagai tempat sakti untuk masyarakat, dengan alasan makhluk halus menuntut niat yang telah tercapai sehingga ia menderita penyakit yang tak bisa diobati secara medis. Masyarakat Prabumulih pada saat ini melakukan pengobatan melalui dukun yang dikenal dengan "Menyan", menunjukkan bahwa masyarakat Prabumulih memiliki tingkat kepercayaan dalam mengobati penyakit yang diderita sendiri.

\section{METODE PENELITIAN}

Penelitian ini dilakukan di Kecamatan Prabumulih Barat Kota Prabumulih Propinsi Sumatera Selatan, karena pada masyarakat setempat, pengobatan tradisional berdasarkan pengobatan kepercayaan. Penyakit yang timbul akibat ada nazar yang pernah diniatkan tapi tidak dilakukan sehingga mengakibatkan individu menderita penyakit. Metode dalam pengumpulan data dengan menggunakan pendekatan kualitatif. Penelitian kualitatif merupakan jenis penelitian formatif yang secara khusus memberikan teknik untuk memperoleh jawaban atau informasi mendalam. Metodologi kualitatif merupakan prosedur penelitian yang menghasilkan data deskriptif berupa kata-kata tertulis maupun lisan dari orang dan perilaku yang diamati (Sumantri, 2011;167). Penulis mencoba mengamati, memahami makna perbuatan masayarakat menurut kebudayaan yang berlaku dalam masyarakat itu sendiri.

Teknik pengumpulan data dengan melakukan wawancara, studi pustaka dan observasi. Observasi dilakukan pada ruang (tempat), pelaku, kegiatan, objek, perbuatan, kejadian atau peristiwa, waktu dan perasaan, dengan tujuan untuk menyajikan gambaran realistik perilaku atau kejadian untuk membantu mengerti perilaku manusia dan untuk evaluasi melakukan pengukuran terhadap aspek tertentu serta melakukan umpan balik terhadap pengukuran tersebut (Sumantri,2011;173). Observasi dilakukan pada masyarakat Prabumulih Barat dalam melakukan pengobatan tradisional dengan melepaskan nazar ke Prabumulih Timur, sebagai tempat yang dianggap keramat bagi masyarakat Prabumulih Barat.

Pengumpulan data dibutuhkan dalam rangka berintegrasi dan berkomunikasi secara langsung dengan masyarakat sebagai subjek penelitian. Dengan demikian teknik penelitian yang dilakukan berupa cara pengamatan terlibat (participant Observation) dan wawancara (interview). Penggunaan

${ }^{1}$ Dari hasil survey awal pada 7 Maret 2017 dengan ketua Menyan Kelurahan Gunung Kumalo dan Payuputat serta ketua Menyan Kabupaten Azadin, mantan ketua DPRD Prabumulih, masyarakat Prabumulih pada umumnya mempercayai penyakit yang bersifat gaib sehingga pengobatan dilakukan berupa memberikan sesajian di mana ia kena serangan penyakit, seperti di hutan, di sungai atau belum membayar nazar yang pernah diucapkan. Bahkan begitu mewabah pada masyarakat, maka dusun tersebut melakukan sedekah dusun. Rata-rata dalam satu tahun sekali, sedekah dusun terus dilakukan dalam rangka menolak bala dari serangan penyakit yang mewabah. 
pengamatan terlibat mempunyai tujuan untuk mengetahui perilaku masyarakat dengan berbaur dan menyatu dalam kehidupan keseharian masyarakat dalam pengobatan tradisional sehingga dapat diketahui jenis-jenis penyakit yang dialami oleh masyarakat itu sendiri, sebab akibat penyakit itu muncul serta cara pengobatan yang dilakukan oleh dukun.

Wawancara merupakan alat (re-cheking) atau pembuktian terhadap informasi atau keterangan yang diperoleh sebelumnya. Teknik wawancara yang digunakan adalah wawancara mendalam. Wawancara mendalam in-depth interview adalah proses memperoleh keterangan untuk tujuan penelitian dengan cara tanya jawab sambil bertatap muka antara pewancara dengan informan atau orang yang diwawancarai dan atau tanpa menggunakan pedoman (guide) wawancara, di mana pewawancara dan informan terlibat dalam kehidupan sosial yang relatif lama (Sumantri,2011:171). Wawancara dilakukan bertujuan untuk memperoleh data langsung tentang kehidupan masyarakat yang melakukan pengobatan tradisional dengan dukun dan masyarakat pengguna jasa dukun. Pelaksanaan wawancara dilakukan secara informal, agar tercipta suasana spontan dan tidak ada jarak peneliti dan subjek penelitian.

Studi kepustakaan yaitu mengumpulkan artikel, buku ataupun tulisan-tulisan yang dapat memberikan informasi tentang permasalahan penelitian. Dalam penelitian ini selain wawancara yang juga merupakan data primer, namun data sekunder diperlukan untuk penunjang data dan proses analisa maka diupayakan dari studi kepustakaan dalam bentuk arsip, dokumen dan artikelartikel laporan penelitian serta sumber bacaan lain.

\section{PEMBAHASAN}

\section{Kota Prabumulih}

Kota Prabumulih merupakan satu dari empat kota yang ada di Propinsi Sumatera Selatan, 8 merupakan pemekaran dari Kabupaten Muara Enim pada tahun 2001. Luas Kecamatan Prabumulih Barat sekitar 61,34 km2 dimana Kelurahan Payuputat merupakan kelurahan yang memiliki wilayah terluas dengan luas wilayah sebesar 30,19 km2 atau sekitar 49,22 persen dari luas Kecamatan Prabumulih Barat sedangkan Muntang Tapus merupakan wilayah yang terkecil. Kota Prabumulih dibentuk berdasarkan Undang-undang Republik Indonesia Nomor 6 Tahun 2001 tentang Pembentukan Kota Prabumulih dan kemudian diresmikan menjadi Pemerintah Kota pada tanggal 17 Oktober 2001 yang terdiri dari 14 desa. Pada tingkat Kecamatan, 12 Kelurahan dan 15 Desa. Tahun 2006 Kota Prabumulih berkembang menjadi 6 kecamatan, 22 kelurahan dan 15 desa dan berkembang lagi berdasarkan Peraturan Pemerintah No. 7 Tahun 2007 Kota Prabumulih menjadi 6 Kecamatan, 25 Kelurahan dan 12 Desa $^{2}$. Kota ini memiliki luas wilayah sebesar 434,46 km2 dan terletak antara 3'4' Lintang Selatan dan 104'-105 Bujur Timur dengan ketinggian dari permukaan laut (dpl) berkisar antara 30-54 m. Kecamatan Prabumulih Barat yang berada di wilayah Barat. Secara geografis, Kecamatan Prabumulih Barat berbatasan dengan :

- Bagian Utara berbatasan dengan Kecamatan Lembak Kabupaten Muara Enim dan Kecamatan Tanah Abang Kabupaten Pali.

- Bagian Selatan berbatasan dengan Kecamatan Rambang Kapak Tengah Kota Prabumulih.

\footnotetext{
${ }^{2}$ http://www.kotaprabumulih.go.id/?page id=95 di up date: Jumat, 6 Mei 2017 pukul 12.00 wib
} 
- Bagian Timur berbatasan dengan kecamatan Cambai, Kecamatan Prabumulih Utara dan Kecamatan Prabumulih selatan

- Bagian Barat berbatasan dengan Kecamatan Rambang Dangku Kabupaten Muara Enim

Secara administrasi, Kecamatan Prabumulih Barat terbagi menjadi lima kelurahan, yaitu Kelurahan Gunung Kemala, Kelurahan Patih Galung, Kelurahan Prabumulih, Kelurahan muntang Tapus, Kelurahan Payuputat serta 1 Desa Tanjung Telang. Untuk mempermudah komunikasi dan administrasi dalam pemerintahan setiap kelurahan terbagi menjadi beberapa rukun warga (RW) dan rukun tetangga (RT) sedangkan untuk desa terbagi menjadi dusundusun. Sementara itu kecamatan Prabumulih Barat terdiri 4 dusun, 27 Rukun Warga ( RW ) dan 99 Rukun Tetangga dengan Kelurahan Payuputat memliki jumlah satuan lingkungan setempat sebanyak 10 RW dan 30 RT.

Penduduk Kota Prabumulih berdasarkan penghitungan jumlah penduduk oleh Badan Pusat Statistik (BPS). Jumlah penduduk Kota Prabumulih pada tahun 2015 mencapai 177,078 jiwa yang terdiri dari 89.171 jiwa penduduk laki-laki dan 87.907 jiwa penduduk perempuan. Jumlah tersebut meningkat 2.601 jiwa atau 1,49\% dari 174.477 jiwa pada tahun 2014. Jumlah penduduk pada tahun 2015 sebanyak 30084 jiwa terhadap luas wilayah di Kecamatan Prabumulih Barat sebesar 6134 hektar, didapatkan kepadatan penduduk di Kecamatan Prabumulih Barat sebesar 5 penduduk $/ \mathrm{km}$. Setiap hektar di Kecamatan Prabumulih Barat sebanyak 5 jiwa. Kepadatan penduduk tertinggi terdapat berada di Kelurahan Patih yang mencapai 60 jiwa/hektar, sedangkan terkecil ada di Kelurahan Payuputat dan Desa Telang dengan 1 jiwa/hektar

Di Kecamatan Prabumulih Barat terdapat dua rumah sakit yaitu Rumah Sakit Fadillah yang terdapat di Kelurahan Patih Galung dan Rumah Sakit Pertamina yang berada di Kelurahan Muntang Tapus. Selain itu terdapat dua Puskesmas dan 4 Puskesmas pembantu dan Polindes, dan masingmasing Polindes diketuai oleh bidan kelurahan yang juga bertanggungjawab pada satu pokja di Pos Pelayanan Terpadu (Posyandu). Dari sejumlah sarana kesehatan tersebut terdapat 2 dokter umum, 2 bidan dan 12 perawat yang melayani masyarakat Prabumulih Barat.

Masyarakat Prabumulih Barat tergolong heterogen, baik mata pencaharian, suku, bahasa, karakter dan agama, namun sebagian besar masyarakat Prabumulih Barat menganut agama Islam. Hal ini di dukung oleh 36 tempat ibadah yang tersebar dari berbagai kelurahan yang terdiri dari 24 mesjid dan 12 mushala. Sementara itu agama Kristen Protestan dengan jumlah penganut 106 jiwa memiliki dua gereja dan 1 gereja Khatolik. Sebagian kecil masyarakat Prabumulih Barat menganut agama Budha dan Hindu tidak memiliki sarana tempat ibadahnya dan mereka beribadah pada kecamatan terdekat yang memiliki fasilitas agama tersebut.

\section{Pengobatan Tradisional di Kota Prabumulih}

Pengobatan tradisional melalui kepercayaan dalam kehidupan masyarakat Prabumulih Barat merupakan bagian dari tradisi. Tradisi dalam kamus Antropologi sama dengan istilah adat istiadat yakninya kebiasaan yang bersifat magis-religius dari kehidupan suatu penduduk asli yang meliputi nilai-nilai budaya, norma-norma, hukum dan aturan-aturan yang saling berkaitan dan kemudian menjadi suatu sistem budaya dari suatu kebudayaan untuk mengatur tindakan atau perbuatan manusia dalam kehidupan social (Ariyono dkk,1985;4). Dalam kamus Sosiologi tradisi diartikan sebagai adat istiadat dan kepercayaan yang secara turun temurun dapat dipelihara (Soekanto, 1993;459). 
Kepercayaan adalah salah satu dasar seseorang dalam menentukan pilihan hidupnya. Yang pada diri seseorang dipengaruhi dari dalam dan lingkungan sekitarnya. Biasanya kepercayaan telah ditanamkan semenjak usia dini yang menjadi pedoman dalam menentukan suatu pilihan ${ }^{3}$. Pengobatan tradisional atau pengobatan alternatif juga dianggap sebagai pengganti metode pengobatan modern. Ketika masyarakat mengalami kejenuhan dalam melakukan pengobatan medis maka masyarakat kembali menggali pengobatan leluhurnya yang dikenal pengobatan tradisional. Pengobatan tradisional berdasarkan kepercayaan yang berlaku dalam kehidupan masyarakat melihat bahwa pengobatan modern menganggap manusia lebih bersifat materialistik (darah, daging, dan tulang) serta mengabaikan aspek spritual manusia dan menggunakan pengobatan materialistik pula. Pengobatan tradisional menganggap masalah kesehatan disebabkan oleh roh-roh jahat, kekuatan magis dan ketidakseimbangan energi mistik, maka ia mengabaikan penyebab penyakit yang disebabkan oleh hal-hal yang bersifat materialistik, seperti racun, bakteri atau virus (Zubir,2015;23)

Tradisi pengobatan tradisional sudah berlangsung sekian lama dalam kehidupan masyarakat. Sebelum masyarakat mengenal pengobatan medis dan kedokteran, dukun dipercayai mampu memberikan unsur sehat bagi masyarakat yang menderita penyakit. Kemampuan dukun mampu menerawang penyakit yang dialami oleh penderitaitu sendiri melalui terawang batin. Namun kebiasaan tersebut terus berlanjut bagi masyarakat Prabumulih Barat, cenderung mempergunakan jasa dukun. Kecenderungan masyarakat Prabumulih Barat menggandrungi pengobatan tradisional melalui terawang batin oleh dukun berdasarkan pengamalan yang diterima secara berulang-ulang yang mampu memberikan efek penyembuhan dari penyakit yang di derita oleh masyarakat itu sendiri.

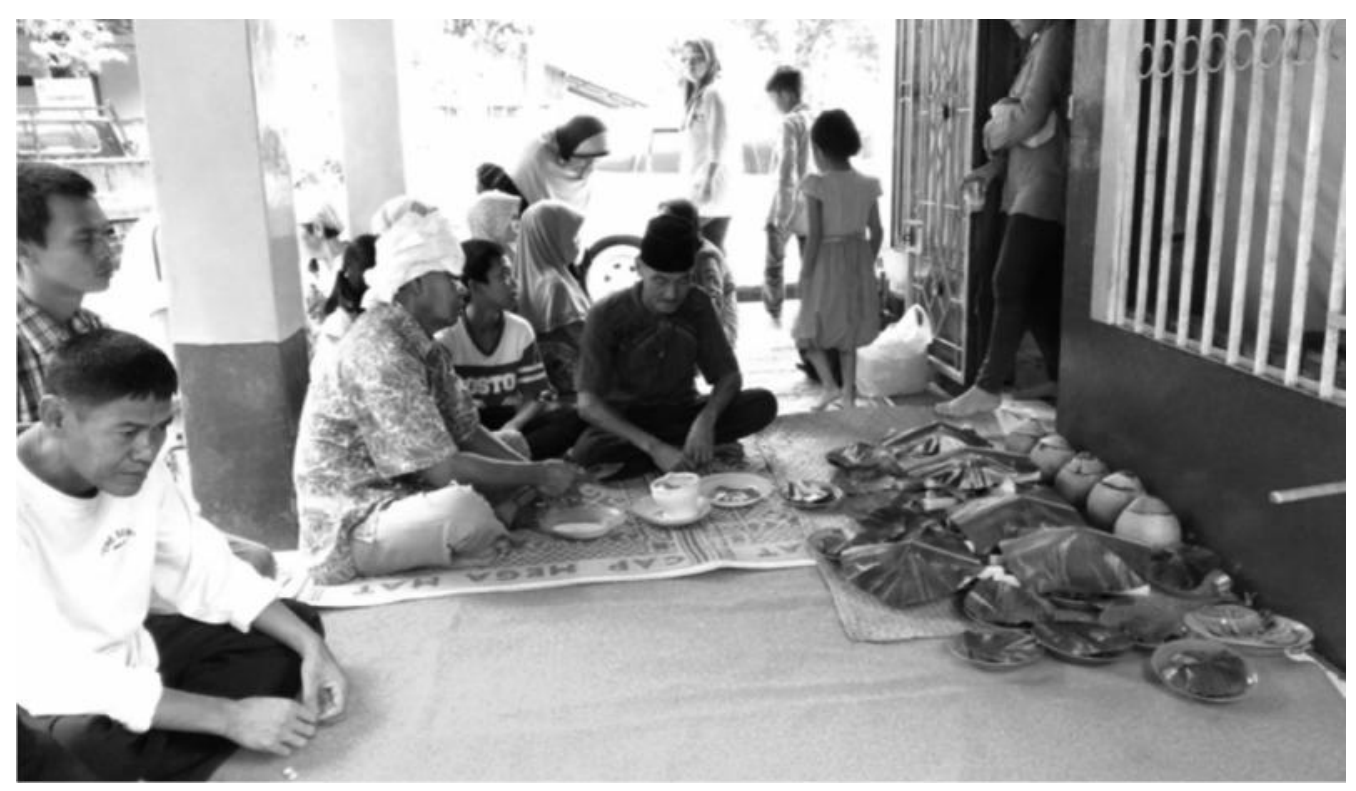

Gambar 1. Masyarakat Prabumulih Barat pergi Ke Gunung Ibul di Prabumulih Timur untuk melepaskan nazar dan sesajian. (Dok.: Rismadona,S.Sos)

${ }^{3}$ Mirna Nur Alia, Artikel :Belian Sasak di tengah Pengobatan Modern, dalam geogle schoor di update: kamis, 16 Maret 2017 pukul 11.00 wib 
Pengetahuan mendominasi terbentuknya suatu tindakan atau perilaku yang menguntungkan seseorang, khususnya dalam melakukan pengobatan tradisional. Pengetahuan merupakan khasanah kekayaan mental secara langsung atau tidak langsung memperkaya kehidupan manusia itu sendiri. Pengobatan tradisional lebih cenderung pada bantuan orang pintar melalui dukun di pengaruhi oleh pengalaman yang diterima dalam kehidupan masyarakat sehingga masyarakat tahu si dukun mampu memberikan unsur sehat dari penyakit yang dideritanya.

Masyarakat Prabumulih masih mempergunakan jasa dukun walaupun Puskesmas dan rumah sakit telah berkembang di daerah tersebut, diakibatkan tingkat pengetahuan yang mereka miliki atau terima turun temurun yang dipengaruhi oleh perkembangan perilaku masa lalu. Teori Behavioral Sociology oleh Poloma menjelaskan hubungan historis antara akibat tingkah laku yang terjadi dalam lingkungan aktor dengan tingkah laku sekarang sehingga mempengaruhi tingkah laku yang terjadi sekarang ini.

Hasil wawancara dengan Asnawi:

(“dulu, puskesmas dan polindes tidak ada, pengobatan yang dilakukan melalui dukun, namun pengobatan tersebut memang mampu menyehatkan, semasa saya masih kecil usia 6 tahun, saya sering sakit-sakitan, saya dibawa ibu saya ke dukun, lalu dikasi sirih kapur dan dikunyah-kunyah, kemudian airnya dioleskan dimana tempat yang sakit tersebut, kata dukun saya ketegoran, karena saya tersenggol anak jin saat bermain")

Tradisi kepercayaan pengobatan tersebut masih berlangsung akibat dari pengalaman masa lalu yang memberikan pasien unsur sehat sehingga kepercayaan pengobatan tradisional melalui dukun terus berlanjut sampai saat ini. Begitu juga wawancara dengan Cik Alim sebagai Ketua Menyan Gunung Kemala berupa:

“Keluarga kami keluarga keturunan dukun, jadi kajinya turun temurun, kami biasa melakukan pengobatan, Insya Allah sehat. Penyakit yang didarita pasien, banyak penyakit gaib, sampai sekarang ini, mereka sudah berobat ke dokter, tapi masih sakit, maka ia datang ke saya. Banyak macam penyakit, ada ketegoran, ada yang bernazar tidak terpenuhi, maka ia juga sakit-sakitan”

Imbalan (reward) yang diterima pasien memberikan efek bagi pasien itu sendiri, terlepas dari penyakit gaib atau tidaknya, namun pasien merasakan sehat setelah berobat melalui dukun sehingga menciptakan perilaku berulang-ulang. Tradisi pengobatan tradisional masih bertahan dalam kehidupan masyarakat Prabumulih khususnya di Gunung Kemala dan Payoputat. Seiring uraian dari hasil wawancara BapakAhmad Azadin, mantan ketua DPRD Prabumulih

"Manusia itu terdiri dari jasad dan roh, penyakit jasad bisa diobati kedokter, penyakit gaib hanya bisa ditangani oleh dukun. Dukun yang tahu apa penyebab penyakitnya, dulu obatnya jasad dengan ramuan, obatnya rohani dengan doa, mantra-mantra secara bathin. Salah satunya orang yang pernah terniat dan bernazar, misalnya dapat anak bernazarkan kambing, maka nazar itu harus dipenuhi, jika tidak si anak sakit-sakitan"

Penyakit terjadi dalam dua bentuk, penyakit jasmaniah yang dirasakan fisik dan penyakit batin yang dirasakan oleh roh. Masing-masing penyakit memiliki penanganan yang berbeda, penyakit jasad ditangani oleh medis dan batin oleh dukun. Pengobatan penyakit batin dilakukan melalui mantramantra dan doa dan penyakit jasmaniah dengan memberikan ramuan obat-obatan. Penyakit gaib diakibatkan oleh niat yang pernah diucapkan pasien, sehingga itu perlu dipenuhi dan begitu dipenuhi pasien itu merasakan sehat. Artinya dalam proposisi stimulus Homans dalam Poloma $(2007 ; 62)$, 
jika di masa lalu terjadi stimulus yang khusus atau seperangkat stimuli, merupakan peristiwa dimana tindakan seseorang memperoleh ganjaran, maka semakin mirip stimuli yang ada sekarang ini dengan yang lalu itu, akan semakin mungkin seseorang melakukan tindakan serupa atau agak sama. Masyarakat yang terbiasa dengan tersebut tidak terpenuhi kemudian terjadi penyakit yang diterimanya, sehingga itu menjadi sebuah kepercayaan tradisi yang dipercayai hingga sampai saat ini.

Berbeda dengan Dede Kurniasih (Kepala Puskesmas Gunung Kemala) yang menyatakan:

\begin{abstract}
"Masyarakat mempercayai jasa dukun, diakibatkan kondisi ekonomi, berobat kedokter sangat mahal, kemudian pusat pengobatan terbatas seperti Puskesmas dan Polindes, penyakit diakibatkan lingkungan sekitar tidak menjamin untuk sehat, seperti jamban tidak ada, Payoputat merupakan wilayah sungai, bila musim hujan, sering terjadi kebanjiran, dan air tergenang, maka nyamuk juga beranak pinak yang menggerogoti warga sehingga masyarakat yang tergigit nyamuk suhu badan panas tidak menentu dan bagi dukun itu ketegoran. Gunung Kemala merupakan wilayah hutan, salah satunya juga nyamuk bersarang ditempat yang sejuk wilayah yang banyak hutan. Bagi kami dari kalangan medis melihat penyakit akibat lingkungan masyarakat, tapi kami tidak pula mengingkari bahwa ada penyakit gaib".
\end{abstract}

Kebertahanan tradisi masyarakat dalam mempercayai pengobatan tradisional melalui dukun diakibatkan faktor ekonomi, dukun tidak membutuhkan biaya pengobatan yang besar, cukup memenuhi syarat untuk berobat saja yang bersifat sukarela. Geografis Payoputat yang merupakan wilayah sepanjang aliran sungai Musi dan Gunung Kemala sering terjadi banjir sehingga menimbulkan air tergenang di wilayah sekitarnya dan akibatnya nyamuk banyak bersarang bahkan berkembangbiak. Wilayah perkebunan karet yang dingin juga mengundang nyamuk untuk hidup berkembangbiak. Penyakit dilihat dari dua aspek yang berbeda secara medis akibat lingkungan yang tidak sehat, secara batin dianggap penyakit gaib, namun masyarakat mempercayai dukun mampu memberikan unsur sehat pada pasien, akibat pengalaman yang diterimanya berulang-ulang kali selain pengobatannya tidak membutuhkan biaya yang besar bagi masyarakat itu sendiri. Artinya, kehidupan masyarakat memiliki dinamika yang selalu berubah-ubah sesuai dengan perkembangan zaman dan kemajuan teknologi. Malcionis dalam Piotr Sztompka, perubahan sosial adalah transformasi dalam organisasi masyarakat dalam pola berpikir dan dalam perilaku pada waktu tertentu ${ }^{4}$. Dari segi pengalaman masyarakat dari dua sisi melalui pengobatan medis dan pengobatan tradisional dapat diterima keduanya sehingga adanya kolaborasi pengetahuan tentang tata cara pengobatan penyakit yang muncul di tengah masyarakat

Selain pengalaman yang mendasarkan individu mengambil keputusan dalam pengobatan tradisional yang bersifat kepercayaan akan dapat menentukan sikap yang diambil oleh individu itu sendiri. Sikap (attitude) merupakan satu predisposisi atau kecenderungan relatif stabil dan berlangsung terus menerus untuk bertingkah laku atau merealisasikan dengan satu cara tertentu terhadap pribadi

\footnotetext{
${ }^{4}$ Definisi perubahan sosial yang terdapat dalam buku ajar sosiologi, terlihat bahwa berbagai pakar meletakkan tekanan pada jenis perubahan yang berbeda. Namun sebagian besar mereka memandang penting perubahan struktural dalam hubungan, organisasi dan ikatan antara unsur-unsur masyarakat. Perubahan sosial adalah transformasi dalam organisasi masyarakat dalam pola berpikir dan dalam perilaku pada waktu tertentu (Macionis, 1987: 638). Perubahan sosial adalah modifikasi atau transformasi dalam pengorganisasian masyarakat (Persell, 1987: 586). Perubahan sosial mengacu pada variasi hubungan antar individu, kelompok, organisasi, kultur dan masyarakat pada waktu tertentu ( Ritzer, et.al, 1987:560). Perubahan sosial adalah perubahan pola perilaku, hubungan sosial, lembaga dan struktur sosial pada waktu tertentu (Farley, 1990:626) Dalam Piotr Sztompka, 2005, Sosiologi Perubahan Sosial, prenada Media, Jakarta.
} 
lain, objek, lembaga atau persoalan tertentu. Sikap dapat dilihat berupa suka, tidak suka, marah dan benci yang bisa penilaian yang diberikan kepada objek. Sikap bisa memberikan respon tertutup dari seseorang terhadap stimulus dari objek tersebut. Sikap mempunyai tiga komponen pokok, berupa: kepercayaan (keyakinan), ide dan konsep terhadap suatu objek kehidupan emosional atau evaluasi terhadap suatu objek, kecenderungan untuk bertindak. Dari hasil wawancara Asnawi:

"Saya berobat kedokter ia juga, ke dukun ia juga, karena pengalaman saya, anak saya sakit usus buntu tidak bisa obat ke dukun, ia menangis terus, lalu saya bawa kedokter, di operasi, baru bisa sembuh. Tapi kakak saya kencing batu, saya bawa ke dokter, pukul 09.00 wib pagi hari mau di operasi, sebelumnya saya ke dukun, pukul 7 pagi dukun datang dengan membawa sebotol air aqua yang telah dimantrainya, sejam kemudian kakak saya mau kencing, lalu ke kamar mandi, keluar batu-batuan kecil dari saluran pipisnya, walau agak dikit perih saat ia keluar, dokter datang untuk mempersiapkan operasi dan men check-up kembali darah dan segala macamnya, bilang pak dokter, bapak udah normal kembali, besok paginya kami kembali pulang”.

Dari hasil wawancara tersebut menjelaskan adanya sikap yang ditunjukan berdasarkan pengalaman yang diwawancarai tersebut, bahwa dalam kehidupan masyarakat adanya kepercayaan yang meyakini pengobatan tradisional dan pengobatan medis dan keduanya saling dapat memberikan unsur sehat.

Sementara itu pandangan masyarakat di kalangan tenaga medis, masyarakat mau berobat akibat fasilitas kesehatan yang telah mendukung sehingga masyarakat terfokus berobat ke dukun mulai beralih melalui pengobatan medis. Sesuai hasil wawancara dengan yaitu ibuk Dede Kurniasih (Kepala Puskesmas Gunung Kemala)

"Semenjak Puskesmas dan Polindes ada, masyarakat menerima keberadaan puskesmas, kami mau berobat ke dokter, bidan"

Didukung oleh Ibuk Amayana dukun beranak dalam hasil wawancaranya menjelaskan;

"Saya dukun beranak, sebelum puskesmas, polindes, dokter, ibuk bidan, rata-rata orang melahirkan datang ke saya atau saya yang datang ke rumahnya. Kadang-kadang terjadi pertengkaran dengan bidan dalam penanganan anak yang baru lahir, semuanya harus seteril, dilarang minum air fatimah karena bilang ibuk bidannya, biarkan ia lahir sesuai waktunya untuk lahir, jika tidak bisa dibawa ke rumah sakit untuk di operasi. Orang tua dulu tidak perlu di operasi, cukup minum ramuan mempermudah melahirkan seperti air rumput fatimah tadi, tapi sekarang orang sudah maju, orang lebih mudah praktis, main bedah saja, biar cepat melahirkan".

Dengan demikian perubahan sikap dalam menentukan pilihan untuk berobat oleh masyarakat diakibatkan fasilitas kesehatan yang mendukung dan pola gaya hidup masyarakat yang praktis. Sehingga kepercayaan terhadap pengobatan tradisional di kalangan masyarakat telah terbagi dua, yaitu percaya kepada dukun dan percaya pula pengobatan medis dengan alasan lebih mudah dan cepat dalam penyembuhananya. Selain pola perubahan gaya hidup modern yang serba praktis, sikap masyarakat dalam berobat juga dipengaruhi oleh tingkat pendidikan, seperti ungkapan wawancara dari Ibuk Asriani seorang (Ibu Rumah Tangga) menuturkan:

"Jika saya perhatikan, anak zaman sekarang, sudah malu berobat ke dukun, mereka banyak ke dokter, ke bidan, apalagi mereka tamatan SLTA, Kuliah, walau ada diantaranya masih juga ke dukun, karena kadang-kadang obat ke dokter belum juga sehat". 
Sikap percaya berobat secara tradisional maupun tenaga medis, diakibatkan tingkat pendidikan merobah pola pikir masyarakat sehingga di kalangan muda berpendidikan cenderung berobat ke tenaga medis dari pada pengobatan tradisional melalui dukun, walau diantaranya kepercayaan terhadap pengobatan melalui dukun tidak hilang serta merta begitu saja, karena diantara masyarakat masih menggandrungi pengobatan tradisional.

Berbeda dengan kalangan tokoh agama dalam menentukan sikap untuk pengobatan tradisonal. Pengobatan tradisional boleh dilakukan sesuai dengan ajaran agama yang dianutnya yang didominasi oleh masyarakat beragama Islam. Namun pemberian sesajian dalam pengobatan itu dianggap tabu, beda hal dengan masyarakat ia tidak peduli terlarang dalam ajaran agama, baginya mampu memberikan unsur sehat. Abdullah Mashud tokoh agama, Payoputat (usia 93) tahun menjelaskan;

"Saya dulu menentang pengobatan tersebut, masyarakat percaya pemberian sesajian itu menyehatkan, tapi kenyataannya ia memang sehat, berarti kita diperbudak oleh syeitan untuk memenuhi keinginannya. Anak-anak saya sakit, saya obat dengan doa dan zikir, sedikit ramuan obat liar yang saya cari, karena dokter belum ada di sini”"

Sikap yang diberikan masyarakat terhadap pengobatan tradisional melalui dukun dan tenaga medis dipengaruhi oleh pengalaman yang diterimanya, pendidikan, dan fasilitas kesehatan yang mendukung serta pola gaya hidup yang praktis serta profesi yang disandang dalam masyarakat tersebut memberikan penilaian yang berbeda namun diantaranya bagi masyarakat yang diperlukan mampu memberikan unsur sehat bagi penderita penyakit itu sendiri.

Perubahan sosial terjadi dalam fungsi dan struktur masyarakat, sesuai dengan pendapat Wilbert Moore yang memandang perubahan sosial sebagai perubahan struktur, pola perilaku dan interaksi sosial. Pengobatan tradisional bukan saja bersandar pada orang pintar melalui dukun tapi juga memberi peluang masyarakat Prabumulih untuk berobat secara modern melalui tenaga medis yang dipercayakan pada dokter atau bidan.

Pola perilaku masyarakat bisa menerima pengobatan medis sehingga pengobatan tradisional yang bersifat kepercayaan mengalami pergeseran. Perubahan tersebut terjadi secara evolusional yang bersifat bertahap. Berawal penerimaan pengobatan medis dan tidak meninggalkan pengobatan tradisional yang bersifat sesajian. Setelah pengalaman yang diterima oleh masyarakat itu sendiri, kemudian penentuan sikap, maka akan muncul tindakan perilaku masyarakat. Tindakan merupakan gerakan responsibility masyarakat yang ditunjukan melalui perilaku. Perilaku merupakan suatu fungsi interaksi antara seseorang individu dengan lingkungannya. Perilaku manusia adalah sebagai suatu fungsi dari interaksi antara person atau individu dengan lingkungannya. Hal ini menunjukan seseorang individu dengan lingkungan menentukan perilaku keduanya secara langsung. Perilaku dapat diambil dari pengalaman serta interaksi manusia dengan lingkungan yang terwujud dalam bentuk pengetahuan, sikap dan tindakan. Wawancara dengan Asnawi menyatakan bahwa:

"Saya percaya dengan dokter dan dukun, maka pengobatan yang saya lakukan sekali dua, tidak bisa dengan dukun maka dengan kedokter atau keduanya yang penting kita sehat"

Hal ini menjelaskan bahwa pengobatan baik secara tradisional maupun secara medis, memberikan unsur sehat, itu menjelaskan adanya kesuksesan dalam pengobatan dari dua mata sisi yang berbeda dan diterima oleh masyarakat. 


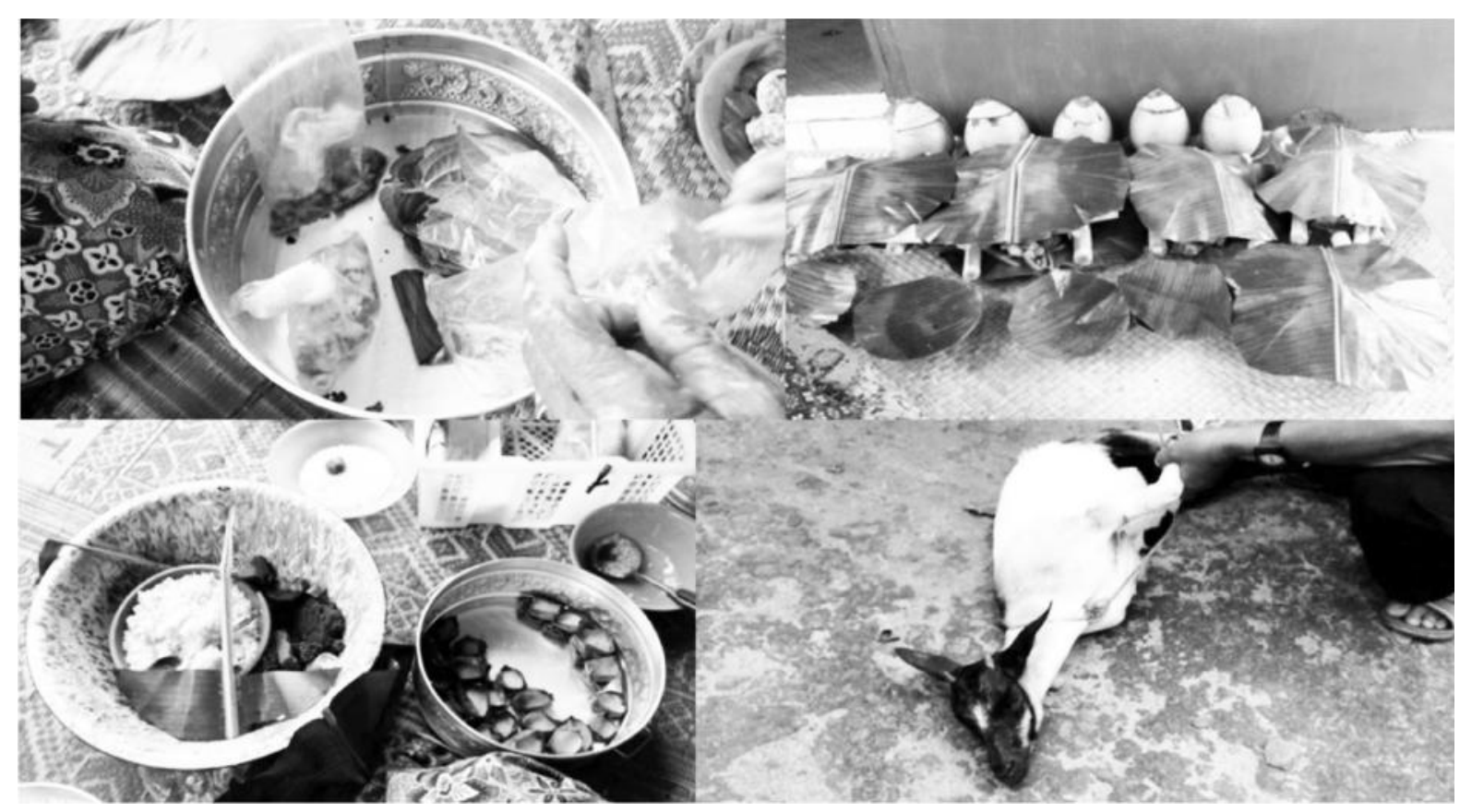

Gambar 2. Pengobatan Tradisional Bersifat Sesajian dan Melepaskan Nazar si Penderita Penyakit. (Dok: Rismadona.S.Sos)

Dalam proposisi sukses Homans menjelaskan dalam setiap tindakan, semakin sering suatu tindakan tertentu memperoleh ganjaran, maka kian kerap ia akan melakukan tindakan itu (Poloma,2007;61). Selagi pengobatan tradisional bisa memberikan unsur sehat bagi penderita penyakit maka pengobatan tersebut masih dimanfaatkan oleh masyarakat, termasuk pengobatan medis. Walau bagaimana proses pengobatan tersebut dianggap diluar rasionalitas seperti yang di ungkapkan Cik Alim dalam wawancara yaitu:

"Saya dalam melakukan pengobatan, saya sering di panggil masyarakat untuk melakukan pengobatan, saya berkomunikasi dengan gaib, dalam pemberian sesajian tersebut ada yang ditinggalkan, misalnya di hutan, maka kaki, kapala, hati dan jantungnya di tinggalkan dan bagian yang lain untuk kita doa makan bersama"

Di tambah hasil wawancara dengan bapak Shohim (ketua Menyan Payo Putat) menjelaskan berupa:

"Dalam melakukan pengobatan, apalagi terjadi penyakit masyarakat mewabah, maka kita melakukan sedekah dusun, kita memberikan sesajian ke sungai, sebelum kesungai, saya panggil yang gaib, bahwa kami menghidangkan makanan, makanlah sekenyangnya, saya tampak ia datang, tapi yang lain tidak, maka begitu ia sudah makan, baru kita lakukan ritual ke sungai”.

Hal ini menjelaskan masyarakat tidak memandang rasional atau tidak dalam pengobatan tersebut, bagi masyarakat dapat merasakan dari pengobatan itu dan memberikan unsur sehat dan kenyamanan bagi fisik masyarakat penderita penyakit itu sendiri. Sehingga pengobatan tradisional tidak hilang dari peredaran akibat adanya perkembangan pengobatan medis. Oleh masyarakat keduanya dianggap saling melengkapi satu sama lain dalam memberikan unsur sehat bagi masyarakat itu sendiri. 
Pengobatan tradisonal dapat memberikan kontribusi bagi pengobatan medis melalui pengobatan herbal yang dilakukan oleh orang pintar selain adanya tradisi kepercayaan. Adanya kolaborasi sistem pengobatan yang dilakukan oleh pihak pemerintahan bidang kesehatan, sesuai hasil wawancara dengan Dede Kurniasih menjelaskan:

"Saya dalam melakukan pengobatan tradisional berkalaborasi dengan dukun, tapi bukan pemberian sesajian, seperti dukun beranak kita bina, dukun patah tulang, dukun pijit kemudian menggali rempah-rempah pengobatan tradisional yang bersifat herbal yang dikenal membudayakan toga".

Artinya tidak semua masyarakat fanatik terhadap pengobatan tradisional atau pengobatan medis, dan pengobatan tersebut memberikan kontribusi dalam mengobati berbagai penyakit. Dalam proposisi stimulus Homans,

"Jika masa lalu terjadinya stimulus yang khusus atau seperangkat stimuli, merupakan peristiwa di mana tindakan seseorang memperoleh ganjaran, maka semakin mirip stimuli yang ada sekarang ini dengan yang lalu itu, akan semakin mungkin seseorang melakukan tindakan serupa atau yang agak sama"

Hal ini mempertegas bahwa dalam pengobatan tradisional selagi mampu memberikan unsur sehat bagi masyarakat, maka pengobatan itu akan tetap bertahan dalam masyarakat, dan jika tidak mampu maka ia akan beralih pada pengobatan medis. Pengobatan tradisional dan pengobatan medis saling melengkapi, maka masyarakat akan memakai keduanya. Pemerintah melihat pengobatan tradisional bukanlah pengobatan kuno dan diluar rasionalitas dan variasi pengobatan yang terbuat dari alam sebagai pengobatan herbal yang tidak beresiko secara kimiawi.

\section{PENUTUP}

Pengobatan tradisional terdiri dari ramuan obat, pengobatan spritual (kebatinan), namun masyarakat Prabumulih khususnya Gunung Kemala dan Payoputat masih mempertahankan tradisi pengobatan aliran kepercayaan dengan memberikan sesajen kepada makhluk gaib. Selain itu juga ada pengobatan tradisional lain berupa ramuan obat-obatan. Penyakit hadir karena ada niat atau nazar yang tidak dilaksanakan sehingga makluk gaib menuntut untuk memenuhi niat yang telah terjanjikan.

Dasar masyarakat melakukan pengobatan tradisional tersebut berdasarkan pengalaman, bahwa pengobatan dengan memberikan sesajen tersebut memberikan efek sehat bagi penderita penyakit itu sendiri sehingga tradisi ini terus bertahan sampai saat ini. Walaupun demikian sesuai dengan perkembangan zaman, telah membagi sikap masyarakat untuk menentukan pilihannya untuk berobat secara medis atau secara tradisional melalui dukun. Kadang kalanya keduanya dipakai sebagai saling melengkapi dalam pengobatan tradisional, pengobatan batin digunakan untuk ketenangan jiwa dan pengobatan medis untuk fisik, karena unsur manusia terdiri dari rohani dan jasmani.

Bentuk perobahan sosial yang terjadi dalam tradisi kepercayaan pengobatan tradisional terjadinya pola pikir dan perilaku masyarakat yang berubah terhadap pengobatan tradisional itu sendiri akibat adanya sehingga terjadinya pergeseran kepercayaan pada pengobatan tradisional dengan mengkalaborasi pengobatan medis dan pengobatan tradisional yang mempercayai penyakit muncul akibat perbuatan yang gaib.

Pemberian sesajen pada pengobatan tradisional, pada mulanya dipersembahkan kepada semua makhluk gaib, kemudian terjadi pergeseran kepercayaan dengan memberikan sebagian kepada makhluk 
gaib dan sisanya untuk makan bersama dalam acara mendoa syukuran. Di lain hal sesajen juga ada yang dihidangkan untuk mendoa bersama tanpa memberikan sesajen sebagai wujud terima kasih kepada Tuhan yang Maha Esa yang telah memberikan riziki, kesehatan dan lain-lain. Pengobatan tradisional dan pengobatan medis mampu memberikan unsur sehat bagi si penderita penyakit dalam kalangan masyarakat itu sendiri, maka perlu melakukan pencerahan pada masyarakat penyebab penyakit yang di terima secara rasional dan membiasakan lingkungan yang bersih.

\section{DAFTAR PUSTAKA}

Agoes ,Azwar dan T.Jacob M.S,M.D,1996, Antropologi Kesehatan Indonesia,Jilid I Pengobatan Tradisional. Penerbit Buku Kedokteran EGC

Ariyono dan Aminudin Siregar,1985, Kamus Antropologi, Jakarta: Akademika Pressindo

Mirna Nur Alia, Artikel :Belian Sasak di tengah Pengobatan Modern, dalam geogle Schoor di update: kamis, 16 Maret 2017 pukul 11.00 wib

Koentjaraningrat, Pengantar Ilmu Antropologi, 2002, Jakarta: Rineka Cipta,

Ritzer,George, 2007, Sosiologi Ilmu Pengetahuan Berparadigma Ganda, Jakarta, Rajagrafindo Persada

Soekanto, Soejono, Sosiologi suatu Pengantar, Jakarta, Rajawali Pers

Soekanto, Soejono,1993, Kamus Sosiologi, Jakarta: RajaGrafindo Persada

Sumantri ,Arif , 2011, Metodologi Penelitian Kesehatan,Jakarta, Kencana Prenada Media Group

Shadily, Hasan,1993,Sosiologi Untuk Masyarakat Indonesia, Jakarta: Rineka Cipta

Undang-undang No.9 tahun 1960 tentang Pokok-pokok Kesehatan

Poloma, Margaret M 2007, Sosiologi Kontemporer, Jakarta Rajagrafindo Persada. 